\title{
HUBUNGAN SHIFT KERJA DAN LAMA KERJA DENGAN KELELAHAN PETUGAS AIR TRAFFIC CONTROLLER (ATC) DI TOWER ATC BANDARA SOEKARNO HATTA
}

\author{
Gin Gin Yulenda ${ }^{1)}$
}

\begin{abstract}
Abstrak
Di Bandara Soekarno Hatta dalam sehari frekuensi pesawat yang take off-landing bisa mencapai 1216 pesawat per hari atau sekitar 72 penerbangan per jam. Berdasarkan rekapitulasi data kondisi petugas ATC Di Bandara Soekarno Hatta pada bulan Februari hingga 11 April 2017, terdapat 50 petugas (2,1\%) ATC yang mengalami kelelahan (Yoga, 2017). Meskipun persentase kelelahan rendah, akan tetapi risiko terjadinya kecelakaan pesawat tinggi. Adapun tujuan dari penelitian ini yaitu mengetahui hubungan shift kerja dan lama kerja dengan kelelahan petugas ATC di Bandara Soekarno Hatta tahun 2017.

Metode yang digunakan dalam penelitian ini adalah analitik observasional dengan pendekatan cross sectional yaitu pendekatan, observasi atau pengumpulan data sekaligus pada suatu saat. Sumber data yang digunakan berasal dari data primer dan data sekunder. Cara penetapan sampel pada penelitian ini dengan menggunakan rumus Slovin sebanyak 185 sampel. Teknik pengambilan sampel menggunakan purposive sampling.

Berdasarkan hasil uji statistik yang telah dilakukan, dapat disimpulkan Sebanyak 29 responden $(49,5 \%)$ petugas ATC mengalami kelelahan rendah, Petugas ATC bekerja dalam 3 shift yaitu pagi, siang, dan malam, Responden yang bekerja $>120$ menit sebanyak 53 orang $(28,6 \%)$, tidak ada hubungan antara shift kerja dengan kelelahan dan Tidak ada hubungan antara lama kerja dengan kelelahan petugas ATC di Tower ATC Bandara Soekarno Hatta.

Saran yang diberikan kepada petugas ATC berkaitan dengan pentingnya pemanfaatan istirahat yang optimal seperti peregangan otot, berjalan-jalan di ruang kantor, berbincang-bincang, dan makanmakanan bergizi. Selain itu peningkatan kerja sama antara petugas ATC dan asisten petugas ATC, dan peningkatan fungsi koordinator ATC.
\end{abstract}

Kata kunci $\quad$ : Kelelahan, petugas ATC, shift Kerja, lama kerja

"Alumni Prodi D4 Kesehatan Lingkungan Poltekkes Kemenkes Tanjungkarang

\section{PENDAHULUAN}

Bandara Soekarno Hatta dalam sehari melayani frekuensi pesawat yang take offlanding mencapai 1.216 pesawat per hari atau sekitar 72 penerbangan per jam. Bandara Soekarno Hatta memiliki petugas ATC sebanyak 341 orang (Rukmono, 2015). Bekerja sebagai petugas ATC membutuhkan konsentrasi tinggi, karena mereka bekerja dibawah tekanan yang cukup tinggi, sehingga jam kerja ATC pun dibatasi maksimal 2 jam per orang, lalu ganti orang hal tersebut disebabkan karena pekerjaan ini memiliki tingkat stress tinggi dan berpotensi besar mengalami kelelahan (Jamalullail, 2016).

Berdasarkan rekapitulasi data kondisi petugas ATC Di Bandara Soekarno Hatta pada bulan Februari hingga 11 April 2017, terdapat
50 petugas $(2,1 \%)$ ATC yang mengalami kelelahan. Meskipun prosentase kelelahan rendah, akan tetapi resiko terjadinya kecelakaan pesawat tinggi. Selain itu kelelahan kerja dapat menimbulkan beberapa keadaan yaitu prestasi kerja yang menurun, fungsi fisiologis motorik dan neural yang menurun, badan terasa tidak enak dan semangat kerja yang menurun. Perasaan kelelahan kerja cenderung meningkatkan terjadinya kecelakaan kerja, sehingga dapat merugikan pekerja sendiri maupun perusahaannya karena adanya penurunan produktivitas kerja. Kelelahan kerja terbukti memberikan kontribusi lebih dari $50 \%$ dalam kejadian kecelakaan kerja di tempat kerja (Setyawati, 2011 dalam Hastuti, 2015).

Faktor-faktor yang berkaitan dengan kelelahan fisik pekerja akibat kerja yaitu status 
gizi, kondisi kesehatan, lama kerja, monotonitas, kerja statis, kondisi sarana dan prasarana tidak ergonomi, masa kerja, faktor psikologis, faktor fisik lingkungan, usia, dan jenis kelamin Tarwaka, 2014 dalam Hastuti, 2015). Selain itu terdapat faktor lain yang mempengaruhi kelelahan, yaitu shift kerja. Dari uraian sebelumnya, telah dibahas mengenai salah satu faktor lama kerja petugas ATC di Bandara Soekarno Hatta. Menurut Suma'mur (1996), Lama kerja tersebut berkaitan dengan lamanya seseorang bekerja dengan baik dalam sehari pada umumnya 6-10 jam Akan tetapi, bagi petugas ATC hanya diperbolehkan bekerja maksimal 2 jam, kemudian mereka diberi waktu istirahat selama $1 \mathrm{jam}$, hal tersebut digunakan untuk kehidupan dalam keluarga dan masyarakat, istirahat, tidur, dan lain-lain (Hastuti, 2015).

\section{METODE}

Penelitian analitik observasional ini menggunakan pendekatan cross sectional yang menjelaskan hubungan antara variabel bebas dan variabel terikat melalui pengujian hipotesis. Populasi pada penelitian ini meliputi seluruh petugas ATC di Bandara Soekarno Hatta yang berjumlah 341 orang, yang berasal dari divisi Tower sebanyak 86 orang, APPTMA sebanyak 94 orang, dan ACC/RCS sebanyak 161 orang. Hasil perhitungan sampel menggunakan rumus slovin didapatkan 185 sampel yang diambil dari divisi tower 45 petugas, divisi APP-TMA 51 petugas dan divisi RCS/ACC 88 petugas. Pemilihan sampel sedara purposive, didasarkan pada pertimbangan tertentu yang dibuat oleh peneliti sendiri berdasarkan ciri atau sifat populasi yang sudah diketahui sebelumnya

Responden ditentukan berdasarkan kriteria inklusi yaitu: a) Petugas ATC Bandara Soekarno Hatta yang bertugas pada shift pagi pukul $06.00-14.00$, shift siang pukul $14.00-$ 20.00 , dan shift malam pukul $20.00-06.00$; b) Petugas ATC yang selesai bertugas memandu pesawat; c) Petugas ATC Bandara Soekarno Hatta yang bersedia menjadi responden dan dibuktikan dengan informed consent. Sedangkan kriteria eksklusi adalah: a) Petugas ATC Bandara Soekarno Hatta yang tidak bersedia berpartisipasi dalam penelitian; b Petugas yang berada di Tower ATC Bandara Soekarno Hatta tetapi bukan petugas ATC Bandara Soekarno Hatta.

\section{HASIL}

\section{Tingkat Kelelahan Petugas ATC.}

Tabel 1 menjelaskan bahwa mayoritas tingkat kelelahan dari petugas ATC Bandar Soekarno Hatta berada pada katagori normal yaitu sebesar $86,1 \%$, yang mengalami kelelahan sangat tinggi sebesar 5,9\%.

Tabel 1. Tingkat Kelelahan Petugas ATC

\begin{tabular}{clcc}
\hline No & Kelelahan & Frekuensi & Prosentase (\%) \\
\hline 1 & Normal & 126 & 68,1 \\
2 & Rendah & 29 & 15,7 \\
3 & Sedang & 9 & 4,9 \\
4 & Tinggi & 10 & 5,4 \\
5 & Sangat Tinggi & 11 & 5,9 \\
\hline \multicolumn{2}{r}{ Jumlah } & 185 & 100 \\
\hline
\end{tabular}

\section{Hubungan Shift Kerja dengan Kelelahan}

Dari Tabel 2 dapat dijabarkan, pada shift kerja pagi, 68\% responden kelelahan pada katagori normal, $18 \%$ mengalami kelelahan rendah, $8,1 \%$ mengalami kelelahan sedang, $1,6 \%$ mengalami kelelahan tinggi dan $4,8 \%$ mengalami kelelahan sangat tinggi. Pada shift kerja siang $66 \%$ pada katagori kelelahan normal, $13 \%$ rendah, $3,2 \%$ sedang, $11 \%$ tinggi, dan $6,5 \%$ sangat tinggi. Untuk shift malam, $71 \%$ responden mengalami kelelahan normal, $16 \%$ rendah, sedang, $3,3 \%$ sedang, $3,3 \%$ tinggi, $6,6 \%$ sangat tinggi. Hasil analisa statistik menunjukkan $\mathrm{p}$ value $=0,354$, yang berarti tidak ada hubungan bermakna antara shift kerja dengan tingkat kelelahan pada petugas ATC Bandara Soekarno Hatta. 
Tabel 2. Hubungan Shif $t$ Kerja dengan Kelelahan

\begin{tabular}{|c|c|c|c|c|c|c|c|c|c|c|c|c|}
\hline \multirow{3}{*}{ Shift Kerja } & \multicolumn{10}{|c|}{ Kelelahan Kerja } & \multirow{3}{*}{$\mathrm{N}$} & \multirow{3}{*}{$\mathrm{P}$} \\
\hline & \multicolumn{2}{|c|}{ Normal } & \multicolumn{2}{|c|}{ Rendah } & \multicolumn{2}{|c|}{ Sedang } & \multicolumn{2}{|c|}{ Tinggi } & \multicolumn{2}{|c|}{ S. Tinggi } & & \\
\hline & $\mathrm{n}$ & $(\%)$ & $\mathrm{n}$ & $(\%)$ & $\mathrm{N}$ & $(\%)$ & $\mathrm{n}$ & $(\%)$ & $\mathrm{n}$ & $(\%)$ & & \\
\hline Pagi & 42 & 68 & 11 & 18 & 5 & 8,1 & 1 & 1,6 & 3 & 4,8 & 62 & \\
\hline Siang & 41 & 66 & 8 & 13 & 2 & 3,2 & 7 & 11 & 4 & 6,5 & 62 & 0,354 \\
\hline Malam & 43 & 71 & 10 & 16 & 2 & 3,3 & 2 & 3,3 & 4 & 6,6 & 61 & \\
\hline
\end{tabular}

\section{Hubungan Lama Kerja dengan Kelelahan}

Tabel 3 menjelaskan, pada lama kerja yang berisiko, terdapat $1,9 \%$ petugas mengalami kelelahan sangat tinggi. Hasil analisa statistik memperolah $\mathrm{p}$ value 0,109 , dapat diartikan tidak ada hubungan yang bermakna antara lama kerja dengan kelelahan petugas ATC Bandara Soekarno Hatta.

Tabel 3. Hubungan Lama Kerja dengan Kelelaharf

\begin{tabular}{|c|c|c|c|c|c|c|c|c|c|c|c|c|}
\hline \multirow{3}{*}{ Lama Kerja } & \multicolumn{10}{|c|}{ Kelelahan Kerja } & \multirow{3}{*}{$\mathrm{N}$} & \multirow{3}{*}{$\mathrm{P}$} \\
\hline & \multicolumn{2}{|c|}{ Normal } & \multicolumn{2}{|c|}{ Rendah } & \multicolumn{2}{|c|}{ Sedang } & \multicolumn{2}{|c|}{ Tinggi } & \multicolumn{2}{|c|}{ S. Tinggi } & & \\
\hline & $\mathrm{n}$ & $(\%)$ & $\mathrm{n}$ & $(\%)$ & $\mathrm{N}$ & $(\%)$ & $\mathrm{n}$ & $(\%)$ & $\mathrm{n}$ & $(\%)$ & & \\
\hline Beresiko & 38 & 71,7 & 12 & 22,6 & 1 & 1,9 & 1 & 1,9 & 1 & 1,9 & 53 & ( 1 \\
\hline Tidak berisiko & 88 & 66,7 & 17 & 12,9 & 8 & 6,1 & 9 & 6,8 & 10 & 7,6 & 132 & 109 \\
\hline
\end{tabular}

\section{PEMBAHASAN}

\section{Tingkat Kelelahan Petugas ATC}

Pengukuran kelelahan pada petugas ATC terlihat pada tabel 1 . Setelah bekerja, petugas yang merasa lelah pada katagori rendah sebanyak $15,7 \%$, lelah sedang sebanyak $4,9 \%$, lelah tinggi sebanyak $5,4 \%$, dan lelah sangat tinggi sebanyak $5,9 \%$.

Kelelahan petugas bisa menjadi sangat tinggi dikarenakan kondisi kesehatan yang kurang baik, lamanya seseorang bekerja melebihi standar yang ditentukan, faktor psikologis pekerja seperti konflik mental atas pekerjaannya atau orang di sekitarnya, dan shift kerja yang melayani penerbangan selama 24 jam (Suma'mur, 1996). Selain itu, kepadatan pergerakan pesawat yang ramai membuat petugas ATC harus selalu berkonsentrasi tinggi sehingga menyebabkan kelelahan menjadi sangat tinggi (Jamalullail, 2016).

Kelelahan kerja dapat menimbulkan beberapa keadaan yaitu prestasi kerja yang menurun, fungsi fisiologis dan motorik dan neural yang menurun, badan terasa tidak enak dan semangat kerja yang menurun. Perasaan kelelahan kerja cenderung meningkatkan terjadinya kecelakaan kerja, sehingga dapat merugikan diri pekerja sendiri maupun perusahaannya karena adanya penurunan produktivitas kerja. Kelelahan kerja terbukti memberikan kontribusi lebih dari $50 \%$ dalam kejadian kecelakaan kerja di tempat kerja (Setyawati 2011 dalam Hastuti, 2015).

Pada tanggal 18 Juni 2017. Dua pesawat nyaris bertabrakan di landas pacu (runway) Bandara Soekarno Hatta, Cengkareng. Kemungkinan faktor utamanya adalah ketidakjelasan komunikasi. Bisa karena frekuensi radio terlalu padat, atau adanya gangguan splatter termasuk frekuensi. Bisa juga karena pengucapan atau pemahaman yang kurang jelas. Bisa juga karena kelelahan akibat beban kerja melebihi normal, baik pada sisi ATC maupun pilot (Sutrisno, 2017).

Pada tanggal 9 Maret 2017, kejadian nyaris fatal terjadi di kota Hai Pong, Vietnam. Rasa lelah dan kantuk menyerang petugas ATC di Vietnam. 2 pesawat Vietjet berbeda, yang satu ingin take off menuju korea selatan dan yang satu lagi hendak mendarat dari Ho Chi Minh City, keduanya tidak bisa mengontak petugas ATC Bandara Internasional Cat Bi selama kurang lebih 33 menit. Setelah diselidiki, ternyata 2 orang petugas yang seharusnya memberikan arahan kepada pesawat Vietjet tersebut, satunya tidak berada di ruangan, sementara petugas lainnya ketiduran. Akibatnya pesawat terpaksa berputar-putar dulu selama kurang lebih 33 menit, sementara pesawat yang take off juga harus delay sampai petugas ATC memberikan respon (Widodo, 2017). 
Perasaan lelah yang berkadar tinggi dapat menyebabkan seseorang tidak mampu lagi bekerja sehingga berhenti bekerja sebagaimana kelelahan fisiologis mengakibatkan tenaga kerja yang bekerja fisik menghentikan kegiatannya oleh karena merasa lelah bahkan yang bersangkutan tertidur oleh karena kelelahan. Tenaga kerja yang mulai merasa lelah dan dipaksakan untuk terus bekerja, maka kelelahan akan semakin bertambah dan kondisi lelah demikian sangat mengganggu kelancaran pekerjaan serta berefek buruk pada tenaga kerja yang bersangkutan (Suma'mur, 1996).

Berdasarkan data dan fakta mengenai kecelakaan kerja yang terjadi akibat kelelahan cukup tinggi, maka kelelahan perlu dikelola dengan tujuan untuk menekan tingkat kecelakaan dan kerugian akibat kecelakaan. Upaya pencegahan kelelahan berupa penerapan jam kerja dan waktu istirahat sesuai ketentuan yang berlaku, penyelenggaraan tempat istirahat yang memperhatikan kesegaran fisik dan keharmonisan mental psikologis, dan sebagainya (Suma'mur, 1996). Selain itu, peran asisten petugas ATC juga penting. Disaat mendekati jam maksimal pergerakan pesawat, kerjasama petugas ATC dan asisten lebih ditingkatkan. Ketika petugas mulai merasa lelah disaat mendekati waktu pergantian personil petugas ATC, asisten dapat meng-handle tugas petugas ATC. 10 menit sebelum pergantian personil, asisten harus memperhatikan apa yang dikerjakan petugas saat itu, agar asisten tahu apa yang akan ia lakukan selanjutnya (KP 287 Tahun 2015).

Petugas ATC bekerja dalam 3 shift kerja, yaitu pagi, siang dan malam. Responden yang diwawancarai pada shift pagi sebanyak $33,3 \%$, shift siang 33,3\%, dan shift malam $32,8 \%$. Setiap responden yang diwawancarai berasal dari divisi TWR, APP, dan ACC. 62 responden pada shift pagi dan siang berasal dari divisi TWR 15 orang, divisi APP 17 orang dan divisi ACC 30 orang. 61 responden pada shift malam berasal dari 15 orang dari divisi TWR, 17 dari divisi APP dan 29 orang dari divisi ACC.

Shift kerja pagi petugas ATC dimulai pukul 06.00 hingga 14.00 , shift siang pukul 14.00 hingga 20.00 , dan shift malam pukul 20.00 hingga 06.00. Setiap divisi, jam kerja dalam satu shift-nya sama akan tetapi tidak semua divisi yang bekerja dalam satu shift sama jumlah petugasnya. Pada divisi tower, petugas yang bertugas dalam satu shift berjumlah 38 orang, divisi APP 38 orang, dan divisi ACC 64 orang. Petugas ACC berjumlah paling banyak karena berkaitan dengan tugas dan tanggung jawabnya lebih besar, dan jumlah pesawat yang mereka layani lebih banyak dibanding petugas TWR dan APP.

Informasi dari LPPNI pada bulan Maret 2017, rata-rata pergerakan pesawat perhari sebanyak 1216 pesawat yang take off dan landing di Bandara Soekarno Hatta. Shift pagi merupakan waktu kepadatan pesawat tertinggi, bisa mencapai 529 pesawat per hari atau sekitar 66 mov/hours, karena Bandara Soekarno Hatta memiliki 2 buah runway, artinya setiap petugas ATC melayani 33 penerbangan per jam. Pada shift siang kepadatan tertinggi mencapai 132 pesawat per hari atau sekitar 22 mov/hours, yang berarti setiap petugas melayani 11 penerbangan per jam. Pada shifi malam kepadatan tertinggi mencapai 491 pesawat, atau sekitar 49 mov/hours, yang berarti setiap petugas melayani 25 pesawat per jam.

Jarak minimum antara dua pesawat yang take off dan landing adalah 5 Nautical Miles $(\mathrm{Nm})$. Kecepatan atau speed pesawat terbang saat akan mendarat lebih kurang 150 knots. Dengan demikian maka rata-rata separasi jarak $5 \mathrm{Nm}$ tersebut akan membutuhkan waktu kurang lebih 2 menit. Itu berarti setiap runway akan dapat melayani dengan aman 30 pesawat take off landing dalam I jam. Karena di Soekarno Hatta terdapat 2 buah runway, maka pesawat yang dapat dilayani adalah sebanyak 60 pesawat take off dan landing dalam 1 jam. Ini adalah ukuran baku standar yang memenuhi "Safety Factor" di Soekarno Hatta.

Dengan jumlah rata-rata pergerakan pesawat pada shift pagi, dapat dilihat bahwa pergerakan pesawat telah melampaui batas Safety Factor. Sedangkan pergerakan pada shift siang dan malam, masi di bawah standar.

Dengan memperhitungkan penanggulangan bila terjadi emergency, keadaan darurat dan penerbangan yang tidak terjadwal serta pertimbangan cuaca, maka angka 60 itu dikurangi $10 \%$ agar tidak terjadi kesemrawutan bila muncul hal yang tidak diperhitungkan sebelumnya. Berdasarkan standar tersebut maka pergerakan pesawat menjadi 54 atau 56 gerakan take off landing per jam (Hakim, 2017).

Di Bandara Changi, mereka mengelola kapasitas runway sekitar 28 gerakan per jam, jadi untuk 2 runway dengan mempertahankan alur 2 menit separasi, maka dapat melayani 56 take off landing dalam satu jam. 
Traffic pesawat pada arus mudik dan arus balik, seperti puncak lebaran, dapat mencapai 82 mov/hours. Jumlah tersebut telah melampaui batas standar Safety Factor Soekarno Hatta yang hanya 60 mov/hours. Selain itu, berdasarkan Instruksi Mentri Perhubungan No IM 8 Tahun 2017, slot pesawat maksimum untuk Soekarno Hatta adalah 76 mov/hours, jika dibandingkan dengan pergerakan pesawat saat puncak lebaran, maka jumlah tersebut telah melampaui batas standar maksimum.

Di Soekarno Hatta, pertumbuhan penumpang yang dikelola terus meningkat, maka diusahakan pengelola ATC berkoordinasi dengan PT Angkasa Pura II yang menaungi Bandara Soekarno Hatta untuk dapat menambah jumlah "rapid exit taxi way", yaitu taxiway yang dihubungkan dengan landas pacu dengan sudut tajam dan dirancang untuk memungkinkan pesawat udara yang mendarat dapat segera keluar dari runway pada tingkat kecepatan yang lebih tinggi dari yang biasanya dicapai di taxiway yang lain, hal tersebut guna meminimalkan waktu pengguna landas pacu (KP 29 Tahun 2014). Selain itu, diusahakan untuk menerapkan "Holding Stop", yaitu antrian pesawat untuk take off, sehingga mengurangi waktu untuk take off.

Petugas ATC yang bekerja selama $60-120$ menit sebanyak $71,4 \%$, petugas yang bekerja selama $>120$ menit sebanyak $28,6 \%$. Menurut undang-undang Nomor 13 Tahun 2003 tentang ketenagakerjaan, lamanya seseorang bekerja dalam sehari adalah 8 jam atau 40 jam seminggu. Sedangkan untuk lembur, waktu yang diperbolehkan maksimal 3 jam per hari. Makin panjang jam kerja maka makin besar kemungkinan untuk terjadi hal-hal yang tidak diinginkan seperti penyakit dan kecelakaan kerja. Pekerjaan kategori biasa yakni tidak terlalu berat atau ringan, produktivitas seseorang akan menurun setelah 4 jam bekerja. Keadaan ini sejalan dengan penurunan kadar gula dalam darah. Oleh karena itu diperlukan waktu untuk istirahat dan kesempatan makan untuk menambah kembali energi tubuh. Istirahat selama 30 menit setelah bekerja 4 jam kerja terus menerus sangat penting untuk dilakukan (Medianto, 2017).

Sebanyak $28 \%$ petugas ATC bekerja lebih dari dua jam berturut-turut. Berdasarkan KP 287 Tahun 2015, jumlah jam pemanduan pesawat dalam satu hari tidak lebih dari 6 jam, pemanduan paling banyak dilakukan selama 2 jam berturut-turut, dan harus diberikan jeda waktu istirahat selama 1 jam. Itu berarti 28 petugas ATC tersebut telah melampaui batas standar acuan lama kerja dan berisiko mengalami kelelahan kerja.

Petugas ATC yang bekerja lebih dari dua jam, bisa dikarenakan pergerakan pesawat pada jam sibuk meningkat. Khusus di divisi TWR, mereka harus terus memantau pesawat yang take off dan landing di wilayah bandara dengan alat controller working position. Petugas harus bisa mengatur jarak antar pesawat minimum 6 $\mathrm{Nm}$ untuk kedatangan dua pesawat. Dengan minimum dua pesawat tersebut mereka harus memberikan sela untuk satu pesawat yang akan take off. Jumlah antrian pesawat maksimum di taxiway untuk take, off adalah 10 pesawat, antrian pesawat tersebut bisa mencapai 1 jam 30 menit. Sedangkan Petugas APP dan ACC melakukan koordinasi dengan pilot. Mereka mengatur separasi antara satu pesawat dengan pesawat lainnya di udara baik secara vertikal maupun horizontal. Ketinggian vertikal dibedakan $1000 \mathrm{ft}$ antara satu pesawat dengan pesawat lainnya atau horizontal $10 \mathrm{Nm}$ antara satu pesawat dengan pesawat lainnya dengan ketinggian yang sama.

Setiap petugas ATC harus bisa melihat, mendengar, menulis, berpikir, dan berbicara secara serentak. Mereka dilarang berkomunikasi, makan maupun minum saat bekerja. Mereka harus selalu fokus dan berkonsentrasi pada pekerjaan mereka. Hal tersebut membuat mereka tidak sadar akan waktu, sehingga mereka bekerja melebihi standar lama kerja yang ditentukan.

Lamanya seseorang bekerja dengan baik dalam sehari pada umumnya 6-10 jam. Sisanya dipergunakan untuk kehidupan dalam keluarga dan masyarakat, istirahat, tidur, dan lain-lain. Memperpanjang waktu kerja lebih dari kemampuan lama kerja tersebut biasanya tidak disertai efisiensi, efcktivitas, produktivitas, kerja yang optimal, bahkan biasanya terlihat penurunan kualitas dan hasil kerja serta bekerja dengan waktu yang berkepanjangan timbul kecenderungan untuk terjadinya kelelahan, gangguan kesehatan, penyakit dan kecelakaan serta ketidakpuasaan (Ridley, 2008).

Petugas ATC yang bekerja lebih dari 2 jam cenderung mengalami kelelahan. Hal tersebut karena mereka bekerja sangat fokus, sehingga mereka tidak sadar telah melewati batas jam kerja. Oleh karena itu, mereka perlu perlu diingatkan. 
Peran supervisor dan koordinator ATC sangat penting dalam hal ini. Lama kerja petugas bisa dipantau oleh supervisor, karena supervisor bertanggung jawab pada pekerjaan yang berada di lingkupnya supaya berjalan dengan aman dan tidak mengganggu keselamatan karyawan. Dan koordinator bertugas melaksanakan pengawasan, meneliti, memberikan pengarahan-pengarahan teknis dalam rangka pelaksanaan pekerjaan. Selain itu tugas koordinator ATC adalah menyusun jadwal kegiatan petugas, seperti pembagian shift dan tim kerja. Supervisor dan Koordinator bisa mengingatkan kepada petugas ATC untuk istirahat jika jam kerja petugas ATC tersebut sudah mendekati batas pergantian personil. Sehingga petugas yang sering bekerja lupa waktu, dapat segera menyerahkan tugasnya pada asisten atau petugas selanjutnya.

\section{Hubungan Antara Shift Kerja Dengan Kelelahan}

Hasil pada Tabel 2, menunjukan tidak terdapat hubungan antara shift kerja dengan kelelahan petugas ATC bandara Soekarno Hatta. Hal ini berdasarkan pada hasil analisis dengan uji Chi Square dengan hasil nilai $p$ value $0,354(>0,05)$.

Penelitian ini sejalan dengan penelitian yang dilakukan oleh Medianto, 2017 pada tenaga kerja bongkar muat bagian pengangkut pupuk di Pelabuhan Tanjung Emas Semarang, diketahui bahwa tidak ada hubungan antara shift kerja dengan kelelahan.

Tidak adanya hubungan antara shift kerja dengan kelelahan bisa berkaitan dengan tingkat kelelahan. Data menunjukan, sebanyak 29\% petugas ATC mengalami kelelahan rendah. karena kategori kelelahannya rendah, maka konsentrasinya tidak terganggu sehingga petugas bisa bekerja dengan baik. Akan tetapi, meskipun tidak ada hubungan, kelelahan tersebut beresiko tinggi, karena dapat menyebabkan terjadinya kecelakaan, kerusakan alat bahkan korban jiwa.

Shift kerja paling melelahkan yaitu shift pagi, hal tersebut dikarenakan pagi merupakan waktu pergerakan pesawat terpadat, sehingga membuat petugas ATC sangat sibuk, dan harus konsentrasi penuh. Setelah shift pagi, shift malam juga merupakan waktu kerja bergilir yang cukup melelahkan, dikarenakan malam merupakan waktu bagi orang biasanya untuk beristirahat. Shift malam merupakan shift kerja yang waktunya paling panjang, yaitu 10 jam.
Bagi petugas yang belum terbiasa bekerja di shift malam, petugas tersebut akan mudah kelelahan. Shift siang merupakan waktu bekerja dengan pergerakan pesawat paling sedikit, sehingga hanya sedikit kemungkinan timbul kelelahan akibat kerja, akan tetapi 11,3\% petugas ATC yang bekerja shift siang mengalami kelelahan tinggi. Hal tersebut bisa dikarenakan petugas lelah karena melakukan aktivitas berat lain sebelum bekerja.

Irama circandian tiap individu berbeda dalam menyesuaikan kerja terutama terhadap kerja shift di malam hari, namun antara shift pagi dan shift siang terlihat sedikit perbedaan. Berdasarkan hasil kuesioner yang telah dianalisis, perbedaan rerata antara shift siang dan shift pagi sebesar 5,1, secara statistik hasil tersebut tidak signifikan $(p>0,05)$. Tetapi pada umumnya, tenaga kerja yang bekerja pada shift siang akan lebih lelah dari pada bekerja pada pagi hari. Bekerja dengan cara bergilir siang menimbulkan sedikit lebih lelah dibandingkan bekerja pada kerja bergilir pagi. Hal ini disebabkan karena kemungkinan tenaga kerja mengerjakan aktivitas lain sebelum bekerja pada siang, lalu pada malam harinya akan mengakibatkan perasaan lelah sebelum melakukan aktivitas pekerjaan

(Kusumaningtiyas, 2012).

Tidak semua pekerja yang bekerja secara shift mengalami kelelahan, hal tersebut dikarenakan petugas yang bekerja shift, bekerja sama secara tim dan ada rolling waktu. Jika hari ini mereka bertugas pada shift pagi, besok mereka akan bertugas pada shift pagi, esoknya bertugas pada shift malam, dan esoknya lagi bertugas pada shift malam, selanjutnya mereka diberi waktu libur 2 hari. Shift kerja yang diterapkan pengelola ATC yaitu 4 hari kerja 2 hari libur dan 3 hari kerja 1 hari libur. Selain itu Mereka bisa mengelola kelelahan, dengan mengikuti standar kerja yang telah ditetapkan dan beristirahat secukupnya dan akan lebih baik bagi petugas untuk makan-makanan yang bergizi dan tidak melakukan kerja statis sebelum bekerja.

\section{Hubungan Lama Kerja dengan Kelelahan}

Hasil pada Tabel 3 menunjukan tidak terdapat hubungan antara lama kerja dengan kelelahan petugas ATC. Hal ini berdasarkan pada hasil analisis uji Chi Square dengan nilai $p$ value $0,109(>0,05)$.

Penelitian ini tidak sejalan dengan penelitian yang dilakukan oleh Hastuti, 2015 pada pekerja 
konstruksi di PT. Nusa Raya Cipta Semarang diketahui bahwa ada hubungan antara lama kerja dengan kelelahan $p$ value $0,002(<0,05)$. Lelahnya pekerja tersebut karena mereka memiliki jam kerja dalam sehari yang beresiko yaitu lebih dari 8 jam, walaupun tidak semua pekerja memiliki jam kerja yang beresiko akan tetapi pekerja konstruksi melakukan sebagian besar pekerjaan secara manual, berulang-ulang dan terlalu memaksakan sikap kerja sehingga mengakibatkan pekerja mudah mengalami kelelahan.

Petugas ATC di Bandara Soekarno Hatta memiliki cara untuk mengelola kelelahan saat bekerja, seperti beristirahat ketika waktunya, bekerja mengikuti standar operasional prosedur yang ada, dan melakukan hal-hal yang bisa menghilangkan kelelahan kerja. Selain itu, dari manajemen ATC pun, memberikan fasilitas ruang istirahat yang dilengkapi dengan media hiburan, seperti surat kabar dan televisi, sehingga rasa lelah setelah bekerja menjadi berkurang, bahkan hilang.

Standar bekerja petugas ATC yaitu 2 jam kerja berturut-turut dan 1 jam istirahat. Hal tersebut guna meminimalisir kelelahan. Kelelahan juga bisa hilang dengan istirahat yang cukup. Sebanyak $70,2 \%$ petugas ATC beristirahat lebih dari $2 \mathrm{jam}$. Hal tersebut berarti petugas mengalami kelelahan, sehingga mereka beristirahat lebih lama. Dengan istirahat lebih dari 2 jam, rasa kelelahan tersebut akan hilang. Dan sebaliknya, petugas yang beristirahat 1-2 jam saja, berarti petugas tidak mengalami kelelahan atau kelelahan setelah bekerja telah berkurang, sehingga setelah beristirahat mereka bisa langsung bekerja.

Lama kerja dengan kelelahan juga berkaitan dengan kepadatan pesawat, semakin padat pesawat, semakin banyak beban kerja yang ditanggung oleh petugas. Kepadatan pesawat per hari dapat mencapai 1216 pesawat yang take off dan landing (Rukmono, 2017). Petugas sering bekerja tidak sadar akan waktu, sehingga mereka bekerja selama lebih dari 2 jam. Dan sebaliknya, Semakin sedikit kepadatan pesawat, hal tersebut bisa menimbulkan kejenuhan pada saat bekerja. Kejenuhan bekerja juga bisa menimbulkan kelelahan. Hal tersebut berdasarkan data kepadatan pesawat pada tanggal 14 bulan Maret yang lalu, pergerakan pesawat hanya 1067 dalam sehari. Pergerakan pesawat terendah adalah pukul 19.00-19.59 yaitu 3 pesawat yang take off dan landing.
Tidak semua pekerja mengalami kelelahan Mereka bisa mengelola kelelahan setelah bekerja dengan cara beristirahat. sebaiknya waktu istirahat digunakan dengan kegiatan seperti peregangan otot, berjalan-jalan di sekitar ruangan, berbincang-bincang dengan teman, dan sebagainya sehingga kondisi tubuh mereka tetap normal. Selain itu terdapat asisten petugas yang wajib membantu petugas ATC. Petugas yang merasa mulai lelah bisa memberikan kewenangan pada asisten untuk membantunya, dengan catatan tetap dalam pengawasan petugas.

\section{SIMPULAN}

1. Sebanyak 49,5\% ! petugas ATC mengalami kelelahan rendah.

2. Petugas ATC bekerja dalam 3 shift yaitu pagi, siang, dan malam. Responden yang bertugas pada shift pagi $33,3 \%$, siang $33,3 \%$, dan malam $32,8 \%$.

3. Responden yang bekerja $>120$ menit sebanyak $28,6 \%$.

4. Tidak ada hubungan antara shift kerja dengan kelelahan petugas ATC di Bandara Soekarno Hatta.

5. Tidak ada hubungan antara lama kerja dengan kelelahan petugas ATC di Bandara Soekarno Hatta.

\section{DAFTAR PUSTAKA}

Rukmono, Tori R, 2017. Peak Hours Report Sektor TWR Maret 2017, Tangerang.

Jamalullail, Azmi, 2016. Begini Kerja Para Pemandu Lalu Lintas Udara di Bandara Soekarno-Hatta, Tribun News, 7 Juli 2016.

Setyowati, Dina Lusiana dkk, 2014. Penyebab Kelelahan Kerja Pada Pekerja Mebel, (online), Vol. 8, No. 8, diakses 2 Juni 2017 , sl.undip.ac.id/index.php/jkm)

(http://cjournal-

Suma'mur, 1996. Higiene Perusahaan dan Kesehatan Kerja, PT Toko Gunung Agung, 321 Halaman.

Sutrisno, E. Dany, 2017. 2 Pesawat Nyaris Tabrakan di Runway, Soal Komunikasi atau Kelelahan?, Detik news, 19 Juli 2017.

Widodo, S Erna., Fahmi, Rizki., Pantaryanto, Novy., 2015. Tingkat Stress Pemandu Lalu Lintas Penerbangan.

KP 29 Tahun 2014. Manual Standar Teknis Dan Operasional Peraturan Keselamatan Penerbangan Sipil-Bagian 139 (Manual of 
Standard Casr-Part 139) Volume I Bandar Udara (Aerodrome).

KP 287 Tahun 2015. Pedoman Teknis Operasional Bagian 69-01 (Advisory Circular Part 69-01) Tentang Lisensi, Rating, Pelatihan Dan Kecakapan Personel Pemandu Lalu Lintas Penerbangan.

Hakim, Chappy, 2017. Problem Serius Dibalik Pesawat yang Gagal Mendarat di Cengkareng, Kompas.com, 20 Juni 2017.
Medianto, Dwi, 2017. Faktor-Faktor yang Berhubungan dengan Kelelahan Kerja pada Tenaga Kerja Bongkar Muat (TKBM) di Pelabuhan Tanjung Emas Semarang, Skripsi Sarjana, Fakultas Kesehatan Masyarakat Universitas Muhammadiyah, Semarang.

Kusumaningtyas, Prisilia, 2012. Pengaruh Shift Kerja Terhadap Kelelahan Subjektif Pada Tenaga Kerja di Bagian Weaving, PT. Tyfountex. 